\title{
Cytological Studies of 4 Species of the Genus Kobresia (Cyperaceae) Collected from Nepal Himalaya
}

\author{
Okihito Yano ${ }^{1}$, Hiroshi Ikeda ${ }^{1 *}$, Mark F. Watson ${ }^{2}$, \\ and Keshab R. Rajbhandari ${ }^{3}$

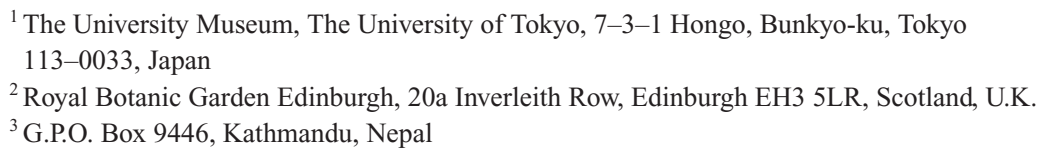

Received October 23, 2010; accepted March 2, 2011

\begin{abstract}
Summary Chromosome numbers of 4 species of the genus Kobresia (Cyperaceae) collected from the Nepal Himalaya are reported. Chromosome numbers of $K$. curvata Kük. $(2 n=50), K$. esenbeckii (Kunth) Noltie $(2 n=66)$, and $K$. duthiei C. B. Clarke $(2 n=c a .84)$ are reported for the first time. Kobresia nepalensis (Nees) Kük. showed an unusually high chromosome number, $2 n=c a$. 114 . It is concluded that chromosomal evolution in the unispicate Kobresia species may have been caused by both polyploidy and aneuploidy.
\end{abstract}

Key words Aneuploid, Cyperaceae, Himalaya, Kobresia, Nepal, Polyploid.

The genus Kobresia Willd. is distributed mainly in the Northern hemisphere, and comprises 50-70 species (Rajbhandari and Ohba 1991, Goetghebeur 1998, Zhang 2001, 2004). High levels of species level diversity is found in Kobresia across the high mountain ranges from the Himalayas to South-West China. Rajbhandari and Ohba (1991) recognized 24 taxa in Kobresia from the Nepal Himalaya, and Zhang (2004) recognized 37 taxa from Tibet. Cytological studies have proven useful for understanding the diversification of several plant groups in the Himalayas (Wakabayashi and Ohba 1988, Akiyama et al. 1992, Ikeda and Ohba 1999). Roalson (2008) enumerated chromosome numbers of Cyperaceae, and reported a few chromosome counts for the genus Kobresia. Previous cytological studies of 7 species of Kobresia have reported chromosome numbers of $2 n=32, \mathrm{ca}$. 36 , 52-56, 58, 60-66, 70-76, 80, ca. 122 (Flovik 1943, Holmen 1952, Löve and Löve 1956, Jørgensen et al. 1958, Knaben and Engelskjøn 1967, Johnson and Packer 1968, Zhukova 1969, Krogulevich 1971, Poghosian et al. 1971, Zhukova and Petrovsky 1976, 1980, Mehra and Sachdeva 1975, 1976, Probatova and Sokolovskaya 1988, Hoshino et al. 1993, 2000, Roalson 2008). However, most of these cytological works used materials collected from the circumpolar regions, and only 2 of the species examined were collected from the Himalayas. Mehra and Sachdeva $(1975,1976)$ reported chromosome numbers of $2 n=80$ for K. royleana (Nees) Boeck., from Kashmir Himalaya in NorthWest India, and Hoshino et al. (2000) reported $2 n=c a .122$ for K. nepalensis (Nees) Kük. from Langtang Himal, in central Nepal. However, in order to understand the evolution and diversification of this genus in the Himalayas, additional karyomorphological studies are needed.

This paper reports chromosome numbers for 4 additional Kobresia species collected from the Manaslu Himalaya and adjacent areas in central Nepal, with the aim to elucidate the chromosomal evolution of this genus.

\footnotetext{
*Corresponding author, e-mail: h_ikeda@um.u-tokyo.ac.jp
} 
Table 1. Species, localities, voucher specimens, and chromosome numbers of 4 species of genus Kobresia collected from the Mt. Manaslu and adjacent regions in Nepal Himalaya

\begin{tabular}{cc}
\hline \hline \multicolumn{1}{c}{ Species, locality and voucher specimen } & Chromosome number $(2 n)$ \\
\hline Kobresia curvata Kük. & 50 \\
Samagaon, on way to Manaslu Base Camp, 4040 m (Ikeda et al. 20814085) & 66 \\
K. esenbeckii (Kunth) Noltie & ca. 84 \\
Samagaon, 3500 m (Ikeda et al. 20814080) & ca. 114 \\
K. duthiei C. B. Clarke & \\
Samagaon, on way to Manaslu Base Camp, 4220 m (Ikeda et al. 20814088) \\
K. nepalensis (Nees) Kük. \\
Lho-Samagaon, 3070 m (Ikeda et al. 20814064)
\end{tabular}

Materials and methods

Karyomorphological observations were conducted on 4 Kobresia species of the mostly collected from the Manaslu Himalaya and adjacent areas in central Nepal (see Ikeda and Watson 2010). Voucher specimens and localities of the material are listed in Table 1. The methods used for preparing the plant material for chromosome observation followed Yano et al. (2010). Voucher specimens are deposited in the Herbarium at the University of Tokyo (TI), with duplicates available in the National Herbarium of Nepal (KATH) and the Royal Botanic Garden Edinburgh (E).

\section{Results and discussion}

The chromosome numbers determined in this study are shown in Table 1. Somatic metaphase chromosomes of these 4 species were very small, less than $1.2 \mu \mathrm{m}$ in length, and they were polycentric, i.e. primary constriction was not observed in any of the species. Chromosome numbers of $2 n=50$ for K. curvata Kük., $2 n=66$ for $K$. esenbeckii (Kunth) Noltie, and $2 n=c a$. 84 for $K$. duthiei C. B. Clarke, were determined for the first time (Fig. 1). The chromosome number of $2 n=c a$. 122 had previously been reported for Kobresia nepalensis by Hoshino et al. (2000), and our count of $2 n=c a$. 114 (Fig. 1) is somewhat different.

In the genus Kobresia, inflorescence structure, paniculate versus unispicate, is used as an important character in intrageneric classification (Kükenthal 1909, Ivanova 1939, Egorova 1983, Rajbhandari and Ohba 1991, Zhang 2001, 2004). Recently, Starr and Ford (2009) reported the monophyly of unispicate species of the genus Kobresia with strong supports in the tribe Cariceae, based on DNA sequence data. In our study, $K$. esenbeckii $(2 n=66), K$. duthiei $(2 n=c a$. 84), and $K$. nepalensis $(2 n=c a$. 114) have unispicate inflorescence. From previous studies, chromosome numbers of unispicate Kobresia species were: $2 n=32$ for $K$. schoenoides (C. A. Mey.) Steud., $2 n=c a$. 36, 52-56, 58, 60-66 for $K$. myosuroides (Vill.) Fiori \& Paol., $2 n=c a .54,58,62$ for $K$. sibirica (Turcz. ex Ledeb.) Boeck., and $2 n=c a .122$ for $K$. nepalensis (Table 2). The unispicate Kobresia species are seen to exhibit a polyploidy series, as well as aneuploids, which might be common in Cyperaceae plants with diffuse centromeric chromosomes. Himalayan species showed high polyploidy, especially the chromosome numbers of $2 n=c a .114$ and $c a .122$ for $K$. nepalensis, which is the highest yet reported for the genus. Our results suggest that $K$. nepalensis, with the numbers $2 n=c a$. 114 and $c a$. 122, may have arisen through polyploidization from ancestors such as $K$. myosuroides or K. esenbeckii as they have the number of $2 n=52-56,58$, and 60-66. Mehra and Sachdeva (1976) suggested that chromosome numbers in the genus Kobresia showed ploidy series on 3 basic numbers, $x=8(2 n=32,40,72), x=9(2 n=54,72)$, and $x=13(2 n=52,78)$, and other chromosome numbers, $2 n=58$ and 76 originating from secondary aneuploidy. In the present study, our results also suggested that the chromosomal evolution in unispicate Kobresia species may have 

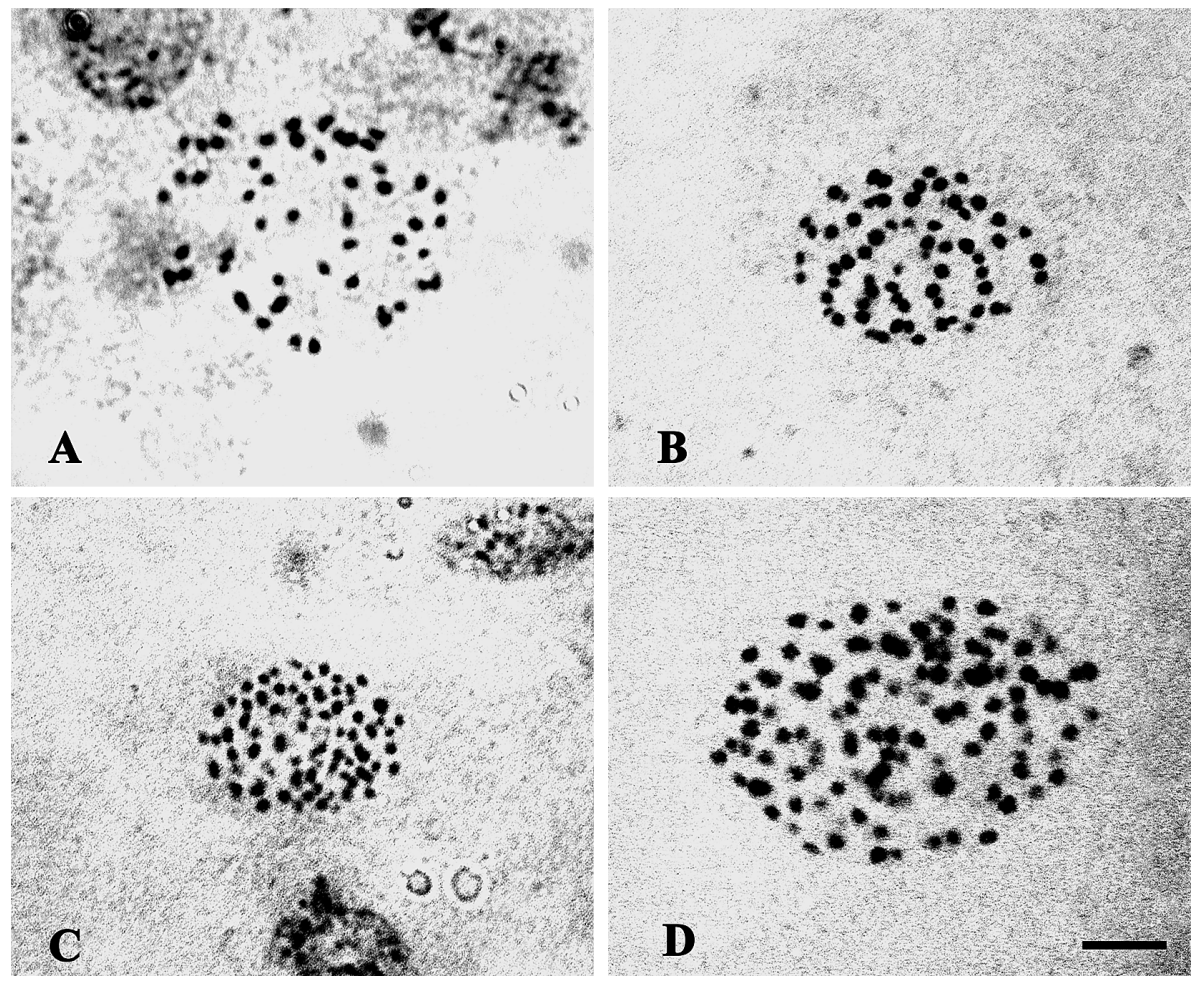

Fig. 1. Photomicrographs of somatic metaphase chromosomes of 4 species in the genus Kobresia. A. $K$. curvata $(2 n=50)$. B. K. esenbeckii $(2 n=66)$. C. $K$. duthiei $(2 n=c a .84)$. D. K. nepalensis $(2 n=c a$. 114). $\mathrm{Bar}=5 \mu \mathrm{m}$.

Table 2. Chromosome numbers of genus Kobresia

\begin{tabular}{|c|c|c|}
\hline Species & $\begin{array}{l}\text { Chromosome } \\
\text { number }(2 n)\end{array}$ & Reference \\
\hline \multicolumn{3}{|c|}{ Unispicate inflorescence species } \\
\hline K. esenbeckii & 66 & Present study \\
\hline K. duthiei & ca. 84 & Present study \\
\hline \multirow[t]{6}{*}{ K. myosuroides } & ca. 36 & Krogulevich (1971; as K. bellardii (All.) Degl.) \\
\hline & $52-56$ & Jøgensen et al. (1958) \\
\hline & 56 & Hoshino et al. (1993; as K. bellardii) \\
\hline & 58 & Johnson and Packer (1968), Zhukova and Petrovsky (1976; as K. bellardii) \\
\hline & $60-66$ & Holmen (1952) \\
\hline & 60 & Löve and Löve (1956; as Elyna myosuroides (Vill.) Fritsch) \\
\hline \multirow[t]{2}{*}{ K. nepalensis } & ca. 112 & Present study \\
\hline & ca. 122 & Hoshino et al. (2000) \\
\hline K. schoenoides & 32 & Poghosian et al. (1971) \\
\hline \multirow{3}{*}{ K. sibirica } & ca. 54 & Johnson and Packer (1968; as K. hyperborea A. E. Porsild) \\
\hline & 58 & Zhukova (1969) \\
\hline & 62 & Zhukova and Petrovsky (1980) \\
\hline \multicolumn{3}{|c|}{ Paniculate inflorescence species } \\
\hline K. curvata & 50 & Present study \\
\hline K. filifolia & ca. 60 & Probatova and Sokolovskaya (1988) \\
\hline K. royleana & 80 & Mehra and Sachdeva $(1975,1976)$ \\
\hline \multirow[t]{6}{*}{ K. simpliciuscula } & 58 & Löve and Löve (1956; as Carex bipartita All.) \\
\hline & 60 & Löve and Löve (1956; as C. bipartita) \\
\hline & 64 & Flovik (1943; as C. bipartita) \\
\hline & $70-75$ & Jøgensen et al. (1958) \\
\hline & $72-76$ & Johnson and Packer (1968) \\
\hline & 76 & Knaben and Engelskjøn (1967) \\
\hline
\end{tabular}


been caused by both polyploidy and aneuploidy.

Previously reported chromosome numbers of Kobresia species with paniculate inflorescences are: $2 n=c a$. 60 for $K$. filifolia (Turcz.) C. B. Clarke, $2 n=58,60,64,70-76$ for $K$. simpliciuscula (Wahlenb.) Mack., and $2 n=80$ for $K$. royleana (Table 2). In our study, K. curvata $(2 n=50)$ has a paniculate inflorescence. Starr and Ford (2009) demonstrated that Kobresia species with paniculate inflorescences were not monophyletic within the tribe Cariceae. With such a mixed phylogenetic history it is currently difficult to recognize chromosome relationships of paniculate Kobresia species only from chromosome numbers. Future cytological and molecular phylogenetical studies are needed including wider sampling in order to fully understand phylogenetics and chromosomal evolution of the genus Kobresia.

\section{Acknowledgments}

The authors extend their appreciation to Dr. L. R. Sharma, former Director General of the Department of Plant Resources, Ministry of Forests and Soil Conservation, Government of Nepal, for his guidance and assistance in conducting field research in Nepal. We also thank the members of the field trip in Nepal in 2008 for their help for collecting plant materials. This study was partly supported by a Grant-in-Aid for Scientific Research (A), No. 18255004 in 2008 (to H. Ohba, Professor Emeritus of the University of Tokyo) from the Japan Society for the Promotion of Science.

\section{References}

Akiyama, S., Wakabayashi, M. and Ohba, H. 1992. Chromosome evolution in Himalayan Impatiens (Balsaminaceae). Bot. J. Linn. Soc. 109: 247-257.

Egorova, T. V. 1983. Generis Kobresia Willd. (Cyperaceae) florae URSS systema et conspectus. Novosti Sist. Vyssh. Rast. 20: 67-85.

Flovik, K. 1943. The chromosome number of some species of Carex and Eriophorum. Ny. Mag. Naturvidensk 83: $77-78$.

Goetghebeur, P. 1998. Cyperaceae. In: Kubitzki, K. (ed.). The families and genera of vascular plants 4. Flowering plants, monocotyledons: Alismatanae and Commelinanae (except Gramineae). Springer, Berlin. pp. 141-190.

Holmen, K. 1952. Cytological studies in the Flora of Peary Land, North Greenland. Medd. Groenl. 128: 1-40.

Hoshino, T., Rajbhandari, K. R. and Ohba, H. 2000. Cytological studies of eleven species of Cyperaceae collected from Central Nepal. Cytologia 65: 219-224.

—, Okamura, K., Hong, D.-Y., Dai, L.-K., Nakata, M. and Tanaka, R. 1993. Cytological studies of Chinese Cyperaceae. 1. Chromosome counts of nine species collected from Jilin, Liaoning and Hebei Provinces. J. Jpn. Bot. 68: 65-69.

Ikeda, H. and Ohba, H. 1999. A systematic revision of genus Potentilla L. section Leptostylae (Rosaceae) in the Himalaya and adjacent regions. In: Ohba, H. (ed.). The Himalayan Plants 3. University of Tokyo Press, Tokyo. pp. 31-117.

— and Watson, M. F. 2010. Plant collecting around Mt. Manaslu in 2008. Newslett. Himal. Bot. 43: 11-13.

Ivanova, N. A. 1939. The genus Kobresia Willd., its morphology and systematics. Bot. Zhurn. 24: 455-503.

Johnson, A. W. and Packer, J. G. 1968. Chromosome numbers in the flora of Ogotoruk Creek, N.W. Alaska. Bot. Not 121: $403-456$.

Jørgensen, C. A., Sorensen, T. J. and Westergaard, M. 1958. The flowering plants of Greenland. A taxonomical and cytological survey. Kongel. Danske Vidensk. Selsk. Biol. Skr. 9: 1-172.

Knaben, G. and Engelskjøn, T. 1967. Chromosome numbers of Scandinavian arctic-alpine plant species. II. Acta Boreal., A. Sci. 21: 1-57.

Krogulevich, R. E. 1971. The role of polyploidy in the genesis of the alpine flora of the Stanovoye Nagorye mountains. The ecology of flora of the Trans-Baikal region. Irkutsk. Izd. Akad. Nauk SSSR. pp. 115-214.

Kükenthal, G. 1909. Cyperaceae-Caricoideae. In: Engler, A. (ed.). Das Pflanzenreich IV. Vol. 20, Heft 38. Wilhelm Engelmann, Leipzig. pp. 1-824.

Löve, A. and Löve, D. 1956. Cytotaxonomical conspectus of the Icelandic flora. Acta Horti Gotob. 20: 65-291.

Mehra, P. N. and Sachdeva, S. K. 1975. In IOPB chromosome number reports. XLIX. Taxon 24: 501-516.

— and - 1976. Cytology of some sedges from northwest India. Cytologia 41: 585-590.

Poghosian, A. J., Narinian, S. G. and Voskanian, V. E. 1971. Materialy karyogeographieskomy isytscheniju flory massiva aragaz. Biol. Zurn. Armenii 24: 36-43. 
Probatova, N. S. and Sokolovskaya, A. P. 1988. Chromosome numbers in vascular plants from Primorye Territory, the Amur River basin, north Koryakia, Kamchatka and Sakhalin. Bot. Zhurn. 73: 290-293.

Rajbhandari, K. R. and Ohba, H. 1991. A revision of the genus Kobresia Willdenow (Cyperaceae) in Nepal. In: Ohba, H. and Malla, S. B. (eds.). The Himalayan Plants 2. University of Tokyo Press, Tokyo. pp. 117-167.

Roalson, E. H. 2008. A synopsis of chromosome number variation in the Cyperaceae. Bot. Rev. 74: 20-393.

Starr, J. R. and Ford, B. A. 2009. Cariceae (Cyperaceae) phylogeny: Current knowledge and future prospects. Bot. Rev. 75 : 110-137.

Wakabayashi, M. and Ohba, H. 1988. Cytotaxonomic study of the Himalayan Saxifraga. In: Ohba, H. and Malla, S. B. (eds.). Himalayan Plants 1. University of Tokyo Press, Tokyo. pp. 71-90.

Yano, O., Ikeda, H., Watson, M. F., Rajbhandari, K. R. and Ohba, H. 2010. Cytological studies on Cyperaceae in the Nepal Himalaya I. Chromosome counts of fourteen species collected from the Manaslu Himalaya, Central Nepal. J. Jpn. Bot. 65: 157-165.

Zhang, S. R. 2001. A preliminary revision of the supraspecific classification of Kobresia Willd. (Cyperaceae). Bot. J. Linn. Soc. 135: 289-294.

- 2004. Revision of Kobresia (Cyperaceae) in Xizang (Tibet). Acta Phytotax. Sin. 42: 194-221.

Zhukova, P. G. 1969. Chromosome number in certain plant species indigenous to the north-east of the USSR. IV. Bot. Zhurn. 54: 1985-1990.

— and Petrovsky, V. V. 1976. Chromosome numbers of some western Chukotka plant species II. Bot. Zhurn. 61: $963-969$.

— and - 1980. Chromosome numbers and taxonomy of some species of the Anyui Mts. Bot. Zhurn. 65: 651-659. 